"Przegląd Prawa Konstytucyjnego" Nr 1 (17)/2014 ------

\title{
Sprawozdanie
}

\section{Doroczna Konferencja Poznańskiego Centrum Praw Człowieka INP PAN 20 lat ochrony praw obywatelek i obywateli Unii Europejskiej: osiagnięcia i wyzwania na przyszłość, Poznań, 23 października 2013 r.}

Dnia 23 października 2013 r. (ogłoszonego Europejskim Rokiem Obywateli) na Wydziale Prawa i Administracji Uniwersytetu im. A. Mickiewicza w Poznaniu odbyła się VI Doroczna Konferencja Poznańskiego Centrum Praw Człowieka INP PAN 20 lat ochrony praw obywatelek $i$ obywateli Unii Europejskiej: osiagnięcia i wyzwania na przyszłość. Patronat nad konferencją objęło Ministerstwo Administracji i Cyfryzacji oraz Przedstawicielstwo Komisji Europejskiej w Polsce, którego dyrektor dr Ewa Synowiec wystąpiła w części powitalnej konferencji. Współorganizatorami konferencji byli: Zakład Praw Człowieka Wydziału Prawa i Administracji Uniwersytetu Warszawskiego, Katedra Prawa Konstytucyjnego Człowieka Wydziału Prawa i Administracji Uniwersytetu im. Adama Mickiewicza w Poznaniu, Katedra Polskiego Prawa Publicznego, Prawa Europejskiego oraz Gospodarczego Uniwersytetu Viadrina oraz Fundacja Konrada Adenauera w Polsce.

Wykład otwierający na temat stanowiska Rządu RP w sprawach dotyczących obywatelstwa Unii Europejskiej rozpatrywanych przez Trybunał Sprawiedliwości UE wygłosił dyrektor Departamentu Prawa Unii Europejskiej w Ministerstwie Spraw Zagranicznych Cezar Herma. Stanowisko Polski zostało ukazane na kilku szczegółowo omówionych przykładach spraw (m.in. Alokpa i inni przeciwko Ministre du Travail, de l'Emploi et de l'Immigration, C-86/12) związanych z prawem pobytu i przemieszczania się między państwami obywateli UE oraz prawami członków ich rodzin.

Pierwszy panel zatytułowany Obywatele Unii Europejskiej jako demos, moderowany przez prof. Mirosława Wyrzykowskiego (Uniwersytet War- 
szawski), rozpoczęło wystąpienie prof. Wojciecha Sadurskiego (Uniwersytet w Sydney, Centrum Europejskie UW). Dotyczyło ono legitymacji demokratycznej Unii Europejskiej w kontekście obywatelstwa europejskiego. Zdaniem prof. W. Sadurskiego spełnianie innych niż demokratyczne wymogów legitymizacji nie jest wystarczające w przypadku UE, natomiast podstawowym elementem jej legitymacji demokratycznej jest demokratyczność władz państwowych krajów członkowskich. Prof. W. Sadurski wskazał również na dwa wymiary obywatelstwa europejskiego, stwierdzając, iż jego wymiar formalnoprawny jest zbyt słaby, by udźwignąć ciężar związany z wymiarem politycznosymbolicznym. W dwóch kolejnych wystąpieniach omówiono instrumenty przysługujące obywatelom UE - petycję do Parlamentu Europejskiego oraz Europejską Inicjatywę Obywatelską. Prof. Bartosz Makowicz (Uniwersytet Viadrina) wyjaśnił, dlaczego wprowadzono petycję do Parlamentu Europejskiego, jakie są przesłanki jej dopuszczalności i skutki jej wniesienia, a także czym petycja różni się od innych form partycypacji. Fiaskiem demokratycznego telos Unii Europejskiej dr Anna Śledzińska-Simon (Uniwersytet Wrocławski) określiła Europejską Inicjatywę Obywatelską. Prelegentka wskazywała na liczne słabości tego instrumentu, m.in. zawiłą procedurę oraz dwukrotną weryfikację inicjatywy przez Komisję, która może odmówić wystąpienia $\mathrm{z}$ wnioskiem legislacyjnym pomimo spełnienia wymogów formalnych przez daną inicjatywę. Senator RP Józef Pinior podzielił się natomiast uwagami na temat Parlamentu Europejskiego jako reprezentacji obywateli UE. Senator J. Pinior przypomniał, iż w przeszłości zrezygnowano z wprowadzenia jednolitych wyborów do Parlamentu Europejskiego, które zagwarantować miało stosowanie jednolitej ordynacji wyborczej, utworzenie ponadnarodowych okręgów wyborczych oraz europejskich partii politycznych. Prelegent zwrócił uwagę na obawy związane z wyborami w 2014 r. i wiążące się z tym ryzyko wejścia do Parlamentu przedstawicieli ruchów antyunijnych i antyimigranckich, oraz przywołał raport Klausa Welle, Sekretarza Generalnego Parlamentu Europejskiego, dotyczący Parlamentu w 2025 r., który zakłada wzmocnienie tego organu.

W drugim panelu, którego moderatorką była prof. Anna Wyrozumska (Uniwersytet Łódzki), podjęto temat praw obywateli Unii Europejskiej. Dr Adam Bodnar (Uniwersytet Warszawski) przedstawił problem realnego wymiaru korzystania z praw wyborczych przysługujących obywatelom 
UE w innych niż kraj pochodzenia państwach członkowskich. O realnym korzystaniu z tych praw w Polsce świadczą liczby: 2 radnych gmin, którzy w momencie wyboru nie byli obywatelami Polski, oraz 501 obywateli innych państw UE zarejestrowanych jako wyborcy. Dr A. Bondar poruszył też w swoim wystąpieniu takie problemy, jak: ograniczenie w Polsce praw wyborczych obywateli UE do szczebla gminnego, nieratyfikowanie przez Polskę Konwencji Rady Europy o uczestnictwie cudzoziemców w życiu publicznym na szczeblu lokalnym oraz pozbawianie przez państwa UE praw wyborczych osób, które skorzystały z prawa do swobodnego przemieszczania się. Wspomniana została również inicjatywa Let me vote rozszerzająca prawa wyborcze obywateli UE na wybory narodowe. Kolejna prelegentka, dr Dorota Pudzianowska (Uniwersytet Warszawski), omówiła warunki nabycia i utraty obywatelstwa UE, przyjmując tezę o autonomizacji pojęcia obywatelstwa europejskiego. Teza ta została poparta przykładami z orzecznictwa Trybunału Sprawiedliwości Unii Europejskiej, którego analiza wskazuje na wpływ instytucji obywatelstwa europejskiego na zakres regulacji sposobu nadawania oraz odbierania obywatelstwa w państwach członkowskich. Dr Marcin Dąbrowski (Uniwersytet Warmińsko-Mazurski) w wystąpieniu na temat członkowstwa obywateli UE w partiach politycznych na tle Konstytucji RP zwrócił uwagę na fakt, iż w obecnym stanie prawnym obywatel Unii Europejskiej może zostać w Polsce radnym gminy, ale nie może należeć do partii politycznej. Dr Filip Jasiński (Ministerstwo Spraw Zagranicznych) poruszył zagadnienie prawa obywateli UE do dostępu do ochrony konsularnej, wskazując na problem zróżnicowanego poziomu ochrony zapewnianego przez konsulaty różnych państw.

Ostatni panel, prowadzony przez prof. Romana Wieruszewskiego, dotyczył zasady niedyskryminacji ze względu na przynależność państwową obywateli Unii Europejskiej. Dr Aleksandra Gliszczyńska-Grabias (Instytut Nauk Prawnych PAN) za najistotniejsze dla skuteczniejszego wdrażania zasady niedyskryminacji na poziomie krajowym uznała zrozumienie i zaakceptowanie idei równości, także przez sędziów, wzmocnienie pozycji organu równościowego, którym jest rzecznik praw obywatelskich, oraz znowelizowanie ustawy o wdrażaniu niektórych przepisów Unii Europejskiej w zakresie równego traktowania. Mgr Anna Czaplińska (Uniwersytet Łódzki) w swoim referacie omówiła skutki zasady niedyskryminacji ze względu 
na przynależność państwową dla praw i wolności osobistych. Rozważania na temat skutków tej zasady w odniesieniu do praw socjalnych i uprawnień majątkowych podjął natomiast dr Maciej Taborowski (Instytut Nauk Prawnych PAN). Oba wystąpienia oparte zostały na analizie wybranych orzeczeń Trybunału Sprawiedliwości UE. Mgr Krzysztof Śmiszek (Polskie Towarzystwo Prawa Antydyskryminacyjnego, Uniwersytet Warszawski) omówił zakaz dyskryminacji ze względu na przynależność państwową w odniesieniu do dyrektyw antydyskryminacyjnych.

Przedstawione referaty zachęciły przybyłych gości do stawiania celnych i interesujących pytań, które dzięki udzielonym na nie odpowiedziom pozwoliły rozszerzyć i pogłębić tematykę konferencji. O potrzebie dyskusji na temat ochrony praw obywatelek i obywateli Unii Europejskiej świadczyło duże zainteresowanie, $\mathrm{z}$ jakim spotkała się konferencja, także ze strony studentów. Kolejne lata pozwolą na dalsze obserwacje rozwoju obywatelstwa europejskiego, którymi z pewnością warto dzielić się nie tylko w Europejskim Roku Obywateli.

Anna Połczyńska Poznańskie Centrum Praw Człowieka INP PAN 